\title{
Strategic Agility Antecedents and Outcomes Field study"
}

Sarah Ezzat Shafiq

Teaching Assistant, Department of Management

Faculty of Commerce

Zagazig University

Journal of Business Research

Faculty of Commerce, Zagazig University

Volume 43 - Issue Three, July 2021

link: https: / /zcom.journals.ekb.eg/ 


\begin{abstract}
The aim of this research is to examine the impact of strategic agility antecedents on organizational performance by mediating strategic agility,and also measuring the impact of strategic agility on organizational performance. The researcher used a descriptive analysis method, Data was collected according to a survey list directed to both top and middle managers of the companies under study,(266) Questionnaire were distributed with a response rate of $(87,6 \%)$. The data was analyzed through the spss programm (26)and the statta programm(16) using a set of non-parametric static methods, due to the nature of the collected data. The results of this research illustrated that there is a positive impact of strategic Agility antecedents on both strategic Agility and Organizational Performance and Strategic Agility mediates the relationship between strategic Agility Antecedents and organizational Performance.

Key words: Strategic Agility, Organizational Performance, Antecedents, Pharmaceutical Companies.
\end{abstract}




\section{Introduction}

In today's fast changing and increasingly global business environment, hardly andy company is safe from competition and more., Now adays, almost all compaines operate in uncertain and dynamic competitive environments (Kettunen, 2010) due to multiple factors, Including Intensified global competition, reduction in lead-time and life expectancy of products, diversification of demand and new technologies, the high level of environmental disturbance leads to paralysis in the organization operations., therefore, managing uncertainty and reducing risks is considered one of the main issues related to thesuccess of the organization and improving its performance (Vagnoni, 2016).

In this competitive world whose future events cannot be predicted, orgainzations must look for other competitive advantages inorder to be able to compete in it, and among those advantages that orgainzation need in this turbulent environment is what is called strategic Agility, where agility gives organizations theability to rapid Response and adaptation to the environment, It also provides the opportunity for organizations to improve their performance and efficiency (Yeganegi, 2012).

\section{Research Problem:}

The pharmaceutical industry in general, and in Egypt in particular, faces a set of risks, Including the Application of the GATT agreement, terms of the world trade organization, the decrease in technology transfer opportunities from international companies as a result of establishing factories for them in Egypt with $100 \%$ capital owned by international companies, the domination of international companies on the Egyptian market and the high prices of pharmaceutical 
raw materials, on which the Egyptian pharmaceutical Industry depends, especially in the current period as a result of the change in the exchange rate, consequently, the performance of the Egyptian pharmaceutical Industry companies must be qualified to face risks and deal with them and achieve a competitive capability that qualifies these companies for exporting abroad, competing in the market.

- From the Research problem the researcher can address the Research Questions as follows:

$R Q_{1}$ :How to improve the organizational performance of Egyptian pharmaceutical companies trough strategic agility?

$R_{2}$ :To what extent do manager of the pharmaceutical Industries sector (Public and private), realize the concept of strategic Agility?

\section{Research importance .}

a)- The scientific importance .

- Due to the scarcity of what was published in the field of strategic agility ,this research is a scientific addition to the Arabic library .

- This research contributes to helping organizations identify the role ofstrategic agility in the development of institutional performance .

b)- The practical importance .

- Attempt to attract the attention of Arab organizations to know the roleof strategic agility on institutional performance for performanceexcellence and upgrading the level of service provided.

\section{Research objectives}

- The main objective of the Research is to study the role of strategic agility in improving organizational performance. 
This objective is divided into several sub-objectives.

RO $_{1}$ : Measure the Impact of strategic agility antecedents on organizational performance by mediating strategic agility.

$\mathrm{RO}_{2}$ : Measuring the Impact of strategic Agility dimensions (strategic sensitivity, clarity of vision, understanding core capabilities, choosing strategic goals, collective commitment) on organizational performance.

\section{Research Hypotheses:}

$\mathrm{H}_{1}$ : There is a statistically significant impact of strategic agility antecedents on strategic agility.

- This hypothesis is divided into several sub-hypotheses.

$\mathbf{H}_{1-1}$ : There is a statistically significant impact of market acuity on strategic agility.

$H_{1-2}$ : There is a statistically significant impact of fluid partnering on strategic agility.

$\mathbf{H}_{1-3}$ : There is a statistically significant impact of Business continuity planning on strategic agility.

$H_{1-4}$ : There is a statistically significant impact of change disposition on strategic agility.

$\mathrm{H}_{1-5}$ : There is a statistically significant impact of information technology on strategic agility.

$H_{1-6}$ : There is a statistically significant impact of organizational learning on strategic agility.

$\mathrm{H}_{2}$ : There is a statistically significant impact of strategic agility antecedents on organizational performance. 
This hypothesis is divided in to several sub- hypothese.

$\mathbf{H}_{2-1}$ : There is a statistically significant impact of market acuity on organizational performance.

$\mathbf{H}_{2-2}$ : There is a statistically significant impact of fluid partnering on organizational performance.

$\mathbf{H}_{2-3}$ : There is a statistically significant impact of Business continuity planning on organizational performance.

$\mathbf{H}_{2-4}$ : There is a statistically significant impact of change disposition on organizational performance.

$\mathbf{H}_{2-5}$ : There is a statistically significant impact of information technology on organizational performance.

$\mathrm{H}_{2-6}$ : There is a statistically significant impact of organizational learning on organizational performance.

$\mathrm{H}_{3}$ : There is a statistically significant impact of strategic agility on organizational performance.

$\mathrm{H}_{4}$ : Strategic Agility mediates the relationship between strategic agility antecedents and organizational performance.

- This hypothesis is divided into several sub- hypotheses.

$\mathrm{H}_{4-1}$ : Strategic Agility mediates the relationship between market acuity and organizational performance.

$\mathbf{H}_{4-2}$ : Strategic Agility mediates the relationship between fluid partnering and organizational performance.

$\mathbf{H}_{4-3}$ : Strategic Agility mediates the relationship between change disposition and organizational performance.

$\mathbf{H}_{4-4}$ : Strategic Agility mediates the relationship between Business continuity planning and organizational performance. 
$\mathrm{H}_{4-5}$ : Strategic Agility mediates the relationship between Information technology and organizational performance.

$\mathbf{H}_{4-6}$ : Strategic Agility mediates the relationship between organizational learning and organizational performance.

\section{Research Variables:}

Dependent variable:- Strategic Agility antecedents (market Acuity, fluid partnering, Business continuity planning, change disposition, Information technology, organizational learning).

- The Researcher used the questionnaire by relying on (ojha, 2008\&kagwa, 2015) scales. Strategic agility antecedents: are defined as the ability of an organization to build, Integrate and reconfigure competencies in order to address rapidly changing environments.

1- Market Acuity : it is the organization's ability to see the competitive environment quickly, Market acuity is considered a valuable competency for the company as it requires constantly searching for information about customer needs and competitors' offers and at the same time has the ability to use this information to create new services and products that are extraordinary for the familiar (Kirca,2005).

2- Change disposition: this concept indicates the extent to which employees believe in the need for change as well as to what extent they believe that such changes are likely to have positive effects on themselves and the organization as a whole (jones, 2005).

3- Business continuity planning: refers to identifying internal and external threats facing the organization and collecting tangible and 
intangible assets to provide effective protection to the organization, while maintaining the competitive advantage (Morganti,2002).

4- Fluid partnering: concept is the organization is ability to change value chain partners quickly and easily in response to changes in the business environment (Hoek, 2001).

5- Technology capability :- Is the collection of techniques, skills , methods and process used in the production of goods and services or in the accomplishment of objectives(Tallon,2006) .

6- Organizational learning:The process by which the organization seeks to improve itsover all capabilities, develop it self, and activate its relation with the environment and adapt to its internal and external conditions (Meer,etal,2003).

Mediator variable: strategic Agility (strategic sensitivity, clarity of vision, choosing strategic goals, Understanding core capabilities, collective commitment).

- The Researcher used the questionnaire by relying on (ojha,2008). Strategic agilityit is the process of intelligently sensing and responding easily and brilliantly to changes in the business environment".

Strategic sensitivity: The sharpness of perception and the intensity of awareness and attention to strategic development)(Adler,2012).

2. Collective commitment: Working together to achieve collective success instead of promoting the personal agenda(Adler,2012) .

3. Clarity of vision :- Represents a clear compelling vision of the ends an organization is working towards and the kinds of relationships and results it hope to create(ojha,2008) . 
4.Core capabilities :- Represents the awareness of an organization of its capability and how these capabilities can be used to create value for its customers (Carpenter\&sanders,2004) .

5.strategic goals:are those goals that are directly related to the organizations mission and are formulated by the organizations mission and are formulated by the organizations top management, often, these goals are the results that require a time frame that exceeds one year to be achieved(Abu,Radi,2013).

Independent variable:- - As for organizational performance, the researcher depends on measuring performance using balanced score card by relying on (figge,etal,2011) scale which contains five dimensions for performance (financial, customers, internal process, learning and growth, social ).

\section{Research limitations:}

- This study was conducted within the following limits:

- This study is limited to the Egyptian pharmaceutical industries sector.

- This study is limited to study the impact of strategic agility onorganizational performance.

- The application of study is limited to top and middle management in thecompanies understudy, this is due to the fact that some previous studiesconfirmed that managers of these departments have the ability to makedecisions and change strategies. 


\section{Literature Review}

1- Akanbi, 2013 "The Role of perceived environment uncertainty and strategic agility on the performance of selected Banks in $0 \%$ state of Nigeria".

* This study aimed at:

- Identifying the impact of uncertainty and strategic agility on performance, and it was applied on banking sector in Oyo state of Nigeria.

- The independent variables of the study are strategic agility (strategic sensitivity, leadership unity, Resource Fluidity) and environmental uncertainty and the dependent variable is performance (sales Revenue, financial strength, performance stability, public Image).

The results illustratedthat:-

- There is a significant relationship between environmental uncertainty , strategic agility and organizational performance.

2- Thomas, (2017), "Relationship between strategic agility and organizational performances".

This study aimed at:

- Identifying the Relationship between strategic agility and organizational performances in 55 company in Kenya.

- The Independent variable is strategic agility (strategic sensitivity, Resource fluidity, collective commitment), the dependent variable is organizational performances (Balanced score card). 
The results illustrated that:-

- There is a significant positive Relationship between strategic Agility and Organizational performance.

\section{Methodology}

In this section we discucss population and sample and data collection procedures as well as the statistical tests used to evaluate the hypothesis. Instrument

In this research, the research adopted the descriptive analytical approach, as the researcher collected secondary data through a comprehensive theoretical review of books, periodicals and scientific references related to the subject of the studyand on reviewing previous studies and thesis related to strategic agility and organizational performance. As for the field and analytical part in this study, the researcher collected the initial data through conducting personal interviews with the manager of the companies under study. Also the researcher adopted in the study the deductive explanatory method in order tocollect data and test hypotheses. The researcher designed a questionnaire to collect the necessary data, and then analyse that data to test the hypotheses of the study.

Study population and sample

The study population can be defined as all the items that the study seeks to generalize to the results related to the study problem, the researcher population is represented in the pharmaceutical industry in the public sector and the pharmaceutical manufacturing companies in the private sector in the 10th of Ramdan city. The number of pharmaceutical companies in each of the public sector is (8) companies for the holding company of pharmaceutical and chemical industries, and the number of 
pharmaceutical companies in the private sector is (7)companies operating in the 10th of Ramdan city.

Only ( 8 )companies have been selected as afield for research and study, and these companies represent $53,3 \%$ of the research population, consequently, the researcher relied on a representative sample of the research population, the following are the companies that represent the research sample :-

1)- companies producing and manufacturing medicines of the holdingcompany for pharmaceuticals" Holiday Pharma"

- Memphis for pharmaceutical \&chemical industries.

- The Nile for pharmaceutical \& chemical industries.

- EIQahera for pharmaceutical \&chemical industries.

-ElArabeya for pharmaceutical \&chemical industries.

- EIGomhoria for medicines and medical supplies.

2)- private sector companies $\left(10^{\text {th }}\right.$ of Ramdan city).

- Egyptian international pharmaceutical industries company (EIPICO). -delta pharmaceutical industries (Delta pharma).

- Mina pharma for pharmaceutical \&chemical industries. Sampling units

The researcher distributed the questionnaire to each of the managers in the top and middle management, as the managers of the top and middle management are responsible for developing and modifying strategies.

The following is a presentation of the Administrative levels under study:A)-Top management:- the board of directors, President, vice president, General Manager. 
B)-Middle Management:- factory manager, department manager.

Research Sample

In light of the previous table, the research sample is determined according to the following criteries:-

- The researcher used the complete Census method with top management members due to their small number of sampling units.

- Regarding the middle management and department head, the researcher also applied complete census method due to their limited numbers.

Table no(1) shows the distribution of the study sample at the top and middle management level of the companies under study.

Table no(1)

The number of questionnaire lists distributed at the top and middle management levels of the companies under study

\begin{tabular}{|c|c|c|c|c|}
\hline \multirow{2}{*}{ Company } & \multicolumn{4}{|c|}{ Distributed questionnaires } \\
\hline & Total & Excluded & Final & $\%$ \\
\hline $\begin{array}{l}\text { Public } \quad \text { Sector } \\
\text { Company: }\end{array}$ & & & & \\
\hline Memphis & 30 & 1 & 29 & 96.7 \\
\hline Nile & 20 & 2 & 18 & 90 \\
\hline El Arabeya & 45 & 17 & 32 & 71.1 \\
\hline El Qahera & 40 & $\mathbf{0}$ & 40 & 100 \\
\hline El Gomhoria & 19 & 4 & 15 & $\mathbf{7 8 . 9}$ \\
\hline $\begin{array}{l}\text { Private Sector } \\
\text { Company: }\end{array}$ & & & & \\
\hline Eipico & 38 & 5 & 33 & 86.8 \\
\hline Mina pharma & 33 & 3 & 30 & 90.9 \\
\hline Delta pharma & 16 & 2 & 14 & 87.5 \\
\hline & 241 & 30 & 211 & 87.6 \\
\hline
\end{tabular}

Source: prepared by the researcher. 


\section{Field study}

\section{Hypotheses testing}

Table (2): Strategic Agility Antecedents, Strategic Agility and Organizational Performance: SEM results

Endogenous variables: Strategic Agility, Organizational Performance Exogenous variables: Market Acuity, Fluid Partnering, Business Continuity Planning, Change Disposition, Information Technology, Organizational Learning

Method: Maximum likelihood (ml) with Satorra-Bentler

\begin{tabular}{|c|c|c|c|c|c|c|}
\hline Paths & $\begin{array}{l}\text { Expecte } \\
\text { d sign }\end{array}$ & $\begin{array}{c}\text { Unstandard } \\
\text { zed } \\
\text { Coefficients }\end{array}$ & $\begin{array}{l}\text { Standardize } \\
\qquad \begin{array}{l}d \\
\text { Coefficients }\end{array}\end{array}$ & $\begin{array}{l}\text { Satorra- } \\
\text { Bentler } \\
\text { Std. Err. }\end{array}$ & $\mathbf{Z}$ & $P>|z|$ \\
\hline \multicolumn{7}{|l|}{ Strategic Agility Equation: } \\
\hline Strategic Agility $\leftarrow$ Market Acuity & + & 0.25449 & 0.30967 & 0.0320 & 7.95 & $0.000 * * *$ \\
\hline Strategic Agility $\leftarrow$ Fluid Partnering & + & 0.20965 & 0.27316 & 0.0390 & 5.37 & $0.000 * * *$ \\
\hline $\begin{array}{l}\text { Strategic Agility } \leftarrow \text { Business } \\
\text { Continuity Planning }\end{array}$ & + & 0.26166 & 0.28653 & 0.0413 & 6.34 & $0.000 * * *$ \\
\hline Strategic Agility $\leftarrow$ Change Disposition & + & -0.00790 & -0.00757 & 0.0313 & -0.25 & 0.801 \\
\hline $\begin{array}{l}\text { Strategic Agility } \leftarrow \text { Information } \\
\text { Technology }\end{array}$ & + & -0.04575 & -0.05092 & 0.0348 & -1.31 & 0.189 \\
\hline $\begin{array}{l}\text { Strategic Agility } \leftarrow \text { Organizational } \\
\text { Learning }\end{array}$ & + & 0.27626 & 0.29361 & 0.0371 & 7.45 & $0.000 * * *$ \\
\hline \multicolumn{7}{|l|}{ Organizational Performance Equation: } \\
\hline Org. Performance $\leftarrow$ Strategic Agility & + & 0.88649 & 1.08596 & 0.1310 & 6.77 & $0.000 * * *$ \\
\hline Org. Performance $\leftarrow$ Market Acuity & + & 0.04784 & 0.07132 & 0.0451 & 1.06 & 0.289 \\
\hline Org. Performance $\leftarrow$ Fluid Partnering & + & -0.00220 & -0.00352 & 0.0363 & .0 .06 & 0.952 \\
\hline $\begin{array}{l}\text { Org. Performance } \leftarrow \text { Business } \\
\text { Continuity Planning }\end{array}$ & + & -0.08713 & -0.11688 & 0.0448 & -1.94 & $0.052 *$ \\
\hline $\begin{array}{l}\text { Org. Performance } \leftarrow \text { Change } \\
\text { Disposition }\end{array}$ & + & 0.06079 & 0.07130 & 0.0275 & 2.21 & $0.027 * *$ \\
\hline
\end{tabular}




\begin{tabular}{|c|c|c|c|c|c|}
\hline $\begin{array}{l}\text { Org. Performance } \leftarrow \text { Information } \\
\text { Technology }\end{array}$ & + & 0.05055 & 0.06892 & 0.0257 & $1.960 .050 *$ \\
\hline $\begin{array}{l}\text { Org. Performance } \leftarrow \text { Organizational } \\
\text { Learning }\end{array}$ & + & -0.15023 & -0.19559 & 0.0349 & $-4.300 .000 * * *$ \\
\hline Log likelihood $=-2333.7073$ & & & & \multicolumn{2}{|c|}{ Number of Obs. $=211$} \\
\hline
\end{tabular}

SOurce: prepared by the researcher.

Notes: $-* * * * *$ and $*$ are significant at the $1 \%, 5 \%$ and $10 \%$ levels respectively.

Test the first major hypothesis and sub-hypothesis arising from it:

The results of the strategic agility equation can test the second major hypothesis of the study, which states that there is a direct statistically significant impact on the strategic agility determinants, as well as the subhypotheses that follow:

- For sub-hypotheses $\boldsymbol{H}_{(1-1)}$; (Market Acuity $\rightarrow$ Strategic Agility) shows a direct positive effect and statistical significance at the level of $\% 1$ for market acuity antecedent on the level of strategic agility in the companies under study (Estimates $=0.25449, H<0.01)$. This supported the acceptance of the $H_{(1-1)}$. The non-standard regression factor indicates that a one-degree increase in market acuity for pharmaceutical companies will increase their strategic agility by an average of $(0.2545)$, or roughly $25 \%$ of the increase in market insights.

- For sub-hypotheses $\boldsymbol{H}_{(1-2)}$, (Fluid Partnering $\rightarrow$ Strategic Agility) the path (strategic agility $=0.20965, H<0.01$ ) shows a direct positive effect and statistically significant at the level of \%1fluid partnering antecedent on the level of strategic agility in the 
companies under $\operatorname{study}($ estimates $=0.20965, H<0.01)$. This supports the realization of the $H_{(1-2)}$ hypothesis. The non-standard regression coefficient suggests that a single-grade increase in partnership liquidity would increase these companies' strategic agility by an average of 0.2097 , or roughly $21 \%$ of the increase in partnership liquidity.

- For $s u b$-hypotheses $H_{(1-3)}$, (Business Continuity $\rightarrow$ Strategic Agility) the path shows a direct positive and statistical impact at the level of $\% 1$ of the Business continuity Planning antecedent on the level of strategic agility in the companies under $\operatorname{study}($ estimates $=$ 0. 26166, $H<0.01)$. This is supported by the realization of the $H_{(1-3)}$. The non-standard regression coefficient indicates that a single-grade increase in business continuity planning in pharmaceutical companies would increase the strategic agility of these companies by an average of 0.2617 degrees, or approximately $26 \%$ of the increase in business continuity planning.

- For sub-hypotheses $\mathrm{H}_{(1-4)}$; (Change Disposition $\rightarrow$ Strategic Agility )the path shows that there is no direct effect on the strategic agility change antecedent in the companies under $\operatorname{study}($ etimates $=$ $-0.00790, H>0.1)$ since the probability value of this route was greater than $10 \%$ and is therefore not statistically significant. This supports the non-realization of the $H_{(1-4)}$.

- For sub-hypotheses $\mathrm{H}_{(1-5)}$; the path (information technology $\rightarrow$ strategic agility) show that there is no direct impact of the information technology antecedent on the level of strategic agility in the companies under study(estimates $=-0.04575, H>$ 0.1 )since the probability value of this route was greater than $10 \%$ 
and is therefore not statistically significant. This supports the nonacceptance of the $H_{(1-5)}$.

- For sub-hypotheses $\boldsymbol{H}_{(1-6)}$; (Organizational Learning $\rightarrow$ Strategic Agility)(strategic agility $=0.27626, H<0.01)$, this path shows a direct positive and statistical impact at the level of $1 \%$ for the organizational Learning antecedent on strategic agility in the companies under study. This supports the acceptance of the $H_{(1-6)}$ hypothesis. The non-standard regression coefficient indicates that a single-grade increase in pharmaceutical companies' organizational learning would increase their strategic agility by an average of 0.2763 , or roughly $27.5 \%$ of the increase in organizational learning.

Thus, we conclude that the actual antecedents of strategic agility for pharmaceutical companies are market acuity, fluid partnering, business continuity planning, and organizational learning only. Using standardized path parameters that standardize units of measurement, and thus reflect the relative importance of variables, The most important antecedent of the strategic agility of pharmaceutical companies was the market acuity with an impact factor $(0.3097)$, followed by organizational learning by a factor $(0.2936)$, business continuity planning $(0.2865)$, and, finally, fluid partnering (0.2732).

The results of the path analysis of the measurements used to create the underlying strategic agility variable have been shown in the study appendix. The route parameters for these measurements can reflect the weights used to create the underlying variable. Using standard parameters (whose transactions reflect the relative importance of variables), the most important variable in the composition of the overall 
indicator of strategic agility was strategic sensitivity (0.8909), followed by choosing strategic goals $(\mathbf{0 . 8 8 8 5})$, understanding core competencies $(0.8818)$, and then clarity of vision (0.7134), Finally, a collective commitment to a factor ( $\mathbf{0 . 6 8 5 2}$ ), which is the least significant measure in the composition of the overall indicator of strategic agility.

Test the second major hypothesis and sub-hypothesis arising from it:

This is where the results of the organizational performance equation can be tested for the second major hypothesis of the study, which states that there is a direct statistically significant impact on the antecedents of strategic agility in the organizational performance level, in addition to the sub-hypotheses emanating from it as follows

- For sub-hypotheses $H_{(2-1)}$, the path (Market Acuity $\rightarrow$ Org. Performance) shows No direct effect of market acuity determinant on organizational performance in the companies under study $($ estimates $=0.04784, H>0.1)$ as the probability value of this route was greater than $10 \%$ and therefore not statistically significant. This supports the non-realization of the $H_{(2-1)}$.

- For sub-hypotheses $\boldsymbol{H}_{(2-2)}$; (Fluid Partnering $\rightarrow$ Org. Performance) the path shows that there is no direct impact of the fluid partnering determinant on the level of organizational performance in the companies under $\operatorname{study}($ estimates $=-0.00220, H>0.1)$ as the probability value of this route was greater than $10 \%$ and therefore is not statistically significant. This supports the non-acceptance of the $H_{(2-2)}$.

- For sub-hypotheses $\mathrm{H}_{(2-3)}$; (Business Continuity $\rightarrow$ Org.Performance ) shows a direct negative effect and statistical significant at the Estimates level $(0.08713, H<$ 
0.1).This supports the acceptance of the $H_{(2-3)}$. The non-standard regression coefficient indicates that a single-stop business planning increase in pharmaceutical companies which reduce their organizational performance by average of $(0.087)$ degrees, or roughly $9 \%$ of the increase in business continuity planning.

- For sub-hypotheses $H_{(2-4)}$; Change Disposition $\rightarrow$ Org. Performance. This path shows that there is a direct positive effect and statistically significant at the level of $5 \%$ of theestimates $=0.06079, P<$ 0.5. This supports the acceptance of the $H_{(2-4)}$ hypothesis. The non-standard regression coefficient indicates that a single-degree change in drug companies' behavior would increase their organizational performance by an average of $(0.0608)$ degree, or roughly $6 \%$ of the increase in behavior change.

- For sub-hypotheses $\left(H_{(2-5)}\right) ;($ Information Technology $\rightarrow$ ORG.Performance). Where this path shows the existence of a positive direct and statistically significant effect at the level of $10 \%$ the information technology antecedent on the level of organizational performance in the study companies. This supported the acceptance of the $\left(H_{(2-5)}\right)$ the non-standard regression coefficient indicates that a single-grade increase in it in pharmaceutical companies will increase their organizational performance by an average of $(0.051)$ degrees, or roughly $5 \%$ of the increase in it.

- For sub-hypotheses $\mathrm{H}_{(2-6)}$; (organizational learning $\rightarrow$ ORG. Performance) where this path shows a direct negative impact and statistical significance at the level of $\% 1$ of the organizational learning antecedent at the level of organizational performance at 
the study companies (Etimates $=-0.15023, H<0.01)$. This supports the acceptance of the $H_{(2-6)}$ hypothesis. The nonstandard regression coefficient indicates that a single-grade increase in drug companies' regulatory learning will increase their organizational performance by an average of 0.1502 degrees, or roughly $15 \%$ of the increase in organizational learning.

Using standardized route parameters whose transactions reflect the relative importance of variables, the most important antecedent for pharmaceutical companies' organizational performance was change disposition of an impact factor(0.0713), followed by information technology with a factor(0.0689), business continuity planning $(-0.1169)$, and finally organizational learning with an impact factor $(-0.1956)$. The results of the path analysis of the measurements used to create the underlying organizational performance variable have been shown in the study appendix. The route parameters for these measurements can reflect the weights used to create the underlying variable. Using standardized parameters (whose transactions reflect the relative importance of variables), the most important variable in the composition of the overall organizational performance indicator was the core of internal processes by a factor $(0.8605)$, followed by the learning and growth axis by a factor (0.8512), the financial axis (0.5335), and the customer axis $(0.8238)$, Finally, an environmental axis with a factor (0.6869), which is the least important measure in the composition of the overall indicator of organizational performance. 
The third main hypothesis test:

Also from the results of the organizational performance equation, the fourth key hypothesis of the study, which states that there is a direct statistically significant impact on the level of effective strategic agility in the organizational performance level, can be tested as follows:

- Where the path (Strategy agility $\rightarrow$ ORG. Performance) shows that the statistically significant positive effect at the level of $\% 1$ for strategic agility on the organizational performance of pharmaceutical companies $($ etimates $=0.8865, \quad P<0.01)$. This supports the acceptance of the fourth major hypothesis. The non-standard regression factor indicates that a single-grade increase in the strategic agility of pharmaceutical companies will increase their organizational performance by an average of $\mathbf{0 . 8 8 6}$ degrees, or approximately $\mathbf{8 9 \%}$ of the increase in strategic agility.

The fourth main hypothesis test and the sub-hypotheses emanating from it: (Results of mediation analysis)

The following table (3) shows the breakdown (or degradation) of the pathways of the previous structural model; This shows the direct impact of strategic agility antecedents on the organizational performance of pharmaceutical companies, as well as the indirect impact of those antecedents on organizational performance through a strategic agility variable, and overall impact that represents the total direct and indirect impact together. This table enables us to test the study's fifth major hypothesis that strategic agility mediates the relationship between the determinants of strategic agility and organizational performance, as well as the sub emerging hypotheses from it, as follows: 
Table (3): Decomposition of effects into total, direct, and indirect

\begin{tabular}{|c|c|c|c|}
\hline Paths & Direct effects & Indirect effects & Total effects \\
\hline Org. Performance $\leftarrow$ Market Acuity & $\begin{array}{l}0.04784( \\
1.06)\end{array}$ & $\begin{array}{l}0.22560( \\
5.06) * * *\end{array}$ & $\begin{array}{l}0.27345( \\
5.82) * * *\end{array}$ \\
\hline Org. Performance $\leftarrow$ Fluid Partnering & $\begin{array}{l}-0.00220(- \\
0.06)\end{array}$ & $\begin{array}{c}0.18585( \\
4.23) * * *\end{array}$ & $\begin{array}{c}0.18365( \\
5.02) * * *\end{array}$ \\
\hline $\begin{array}{l}\text { Org. Performance } \leftarrow \text { Business } \\
\text { Continuity Planning }\end{array}$ & $\begin{array}{l}-0.08713(- \\
1.94) *\end{array}$ & $\begin{array}{l}0.23196( \\
4.50)^{* * *}\end{array}$ & $\begin{array}{l}0.14483( \\
3.31) * * *\end{array}$ \\
\hline $\begin{array}{l}\text { Org. Performance } \leftarrow \text { Change } \\
\text { Disposition }\end{array}$ & $\begin{array}{l}0.06079( \\
2.21)^{* *}\end{array}$ & $-0.00701(-0.25)$ & $0.05378(1.56)$ \\
\hline $\begin{array}{l}\text { Org. Performance } \leftarrow \text { Information } \\
\text { Technology }\end{array}$ & $\begin{array}{l}0.05055 \\
1.96) *\end{array}$ & $-0.04055(-1.30)$ & $0.00999(0.30)$ \\
\hline $\begin{array}{l}\text { Org. Performance } \leftarrow \text { Organizational } \\
\text { Learning }\end{array}$ & $\begin{array}{l}-0.15023(- \\
4.30) * * *\end{array}$ & $\begin{array}{l}0.24490( \\
6.08) * * *\end{array}$ & $\begin{array}{l}0.09467( \\
2.91) * * *\end{array}$ \\
\hline
\end{tabular}

Source: prepared by the researcher.

Notes: - ***, ** and * are significant at the $1 \%, 5 \%$ and $10 \%$ levels respectively

The table shows many interesting results as follows

- For sub-hypotheses $H_{(4-1)}$, path (Market Acuity $\rightarrow$ Org. Performance) is show confidence a statistically positive and statistically significant effect at the level of $\% 1$ for the market acuity antecedent at the level of organizational performance at the companies under study $($ Estimates $=0.27345, H<0.01)$. This total effect also comes entirely from the indirect impact of the market's acuity of regulatory performance through strategic agility. Thus, the level of strategic agility plays the role of mediator (full intermediation) in the relationship of the in-depth market outlook to regulatory performance. This supports the acceptance of the $H_{(4-1)}$. The regression coefficient indicates that a one-degree increase in 
market acuity of pharmaceutical companies would lead to a total increase in their organizational performance by, on average, 0.2735 degrees, through the channel of strategic agility.

- For sub-hypotheses $\left(H_{(4-2)}\right)$; path (Fluid Partnering $\rightarrow$ ORG. Performance) shows a statistically positive impact at the level of $\% 1$ for the antecedent of fluid partneringthe companies under study (Estimates $=0.18365, \mathrm{H}<0.01) . \quad$ This overall impact also comes entirely from the indirect effect of fluid partnering on organizational performance through strategic agility. Thus, the level of strategic agility plays the role of mediator (full mediation) in the relationship of fluid partnering to organizational performance. This support the acceptance of the $H_{(4-2)}$. The regression coefficient suggests that a one-degree increase in fluid partnering in pharmaceutical companies would lead to a total increase in their organizational performance by, on average, 0.1837 , through strategic agility.

- For sub-hypotheses $\left(H_{(4-3)}\right)$; path (Business continuity $\rightarrow($ ORG). Performance) shows a statistically positive impact at the level of $\% 1$ of the Business continuity Planning selector at the level of organizational performance in the companies under study $($ Etimates $=0.14483$, $H<0.01)$. This overall impact is part of the direct impact of business continuity planning on organizational performance, and part of the indirect impact of business continuity planning on organizational performance through the strategic agility. Thus, the level of strategic agility plays the role of mediation (partial mediation) in the business continuity planning relationship with organizational performance. This supports the acceptance of the $H_{(4-3)}$. The regression coefficient 
indicates that a single-grade increase in business continuity planning in pharmaceutical companies would lead to a total increase in their organizational performance by, on average, 0.145 degrees, through direct impact as well as from strategic agility.

- For sub-hypotheses $\left(H_{(4-4)}\right)$; path (Change Disposition $\rightarrow$ (ORG). Performance) shows that there is no total effect on change disposition (Estimates $=0.05378, H>0.1)$. This is because there is only a direct effect of change disposition on the organizational performance level, while there was no indirect effect of changing behavior on organizational performance through the strategic agility channel. So strategic agility does not play role in the relationship between change disposition and organizational performance. This supports the nonacceptance of the $\left(H_{(4-4)}\right)$.

- For sub-hypotheses $\left(H_{(4-5)}\right)$; (Information Technology $\rightarrow$ ORG. Performance) where this path shows that there is no total effect of information technology on the organizational performance of the companies under study $($ Estimates $=0.00999, H>0.1)$. This is because there is only a direct impact of it on organizational performance, while there was no indirect impact of it on organizational performance through the strategic agility channel. So the level of strategic agility does not play role in the relationship with organizational performance. This supports the non-realization of the $H_{(4-5)}$.

- For sub-hypotheses $\left(H_{(4-6)}\right)$; (organizational learning $\rightarrow$ ORG. Performance) where this path shows a total positive impact and statistical significance at the level of $\% 1$ of the organizational learning antecedent at the level of organizational performance at the companies 
under study $($ Estimates $=0.09467, H<0.01)$. This overall impact comes partly from the direct impact of organizational learning on organizational performance and partly from the indirect impact of organizational learning on organizational performance through strategic agility. Thus, the level of strategic agility plays the role of mediator (partial intermediation) in the organizational learning relationship to organizational performance. This supports the acceptance of the $\boldsymbol{H}_{(4-6)}$. The regression coefficient indicates that a one-stop increase in the companies's under study organizational learning would lead to a total increase in their regulatory performance by, on average, 0.0947 degrees, through direct impact as well as from strategic agility.

Thus, according to the Baron and Kenny's three-Step Test, these results indicate that strategic agility may play a role as a "partial intermediation" in the business continuity planning, and organizational learning relationship to organizational performance. It may play a "whole mediation" role in the relationship of market acuity and fluid partnering to organizational performance. In order to formally assess the intermediate variable, the tests of the Sobel, Aroian, and Goodman will be assessed as shown in the following table (4); 
Table (4): Mediation tests:

\begin{tabular}{|c|c|c|c|}
\hline Paths & Sobel test Aroian test & $\begin{array}{l}\text { Goodman } \\
\text { test }\end{array}$ & $\begin{array}{c}\text { Type of } \\
\text { Mediation }\end{array}$ \\
\hline $\begin{array}{l}\text { Performance } \leftarrow \text { Stra. Agility } \leftarrow \\
\text { Acuity }\end{array}$ & $5.1508] * * * \quad[5.1273] * * *$ & {$[5.1746]^{* * *}$} & $\begin{array}{c}\text { Fully } \\
\text { Mediation }\end{array}$ \\
\hline $\begin{array}{l}\text { Performance } \leftarrow \text { Stra. Agility } \leftarrow \\
\text { Fluid }\end{array}$ & $4.2069] * * * \quad[4.1790] * * *$ & {$[4.2354] * * *$} & $\begin{array}{c}\text { Fully } \\
\text { Mediation }\end{array}$ \\
\hline $\begin{array}{l}\text { Performance } \leftarrow \text { Stra. Agility } \leftarrow \\
\text { Continuity }\end{array}$ & $4.6272]^{* * *} \quad[4.6005]^{* * *}$ & {$[4.6543] * * *$} & $\begin{array}{l}\text { Partially } \\
\text { Mediation }\end{array}$ \\
\hline $\begin{array}{l}\text { Performance } \leftarrow \text { Stra. Agility } \leftarrow \\
\text { Disposition }\end{array}$ & {$[-0.2524]$} & {$[-0.2552]$} & $\begin{array}{c}\text { Not } \\
\text { Mediation }\end{array}$ \\
\hline $\begin{array}{l}\text { Performance } \leftarrow \text { Stra. Agility } \leftarrow \\
\text { Technology }\end{array}$ & {$[-1.2888]$} & {$[-1.3026]$} & $\begin{array}{c}\text { Not } \\
\text { Mediation }\end{array}$ \\
\hline $\begin{array}{l}\text { Performance } \leftarrow \text { Stra. Agility } \leftarrow \\
\text { Learning }\end{array}$ & $5.0074] * * * \quad[4.9829] * * *$ & {$[5.0324] * * *$} & $\begin{array}{c}\text { Partially } \\
\text { Mediation }\end{array}$ \\
\hline
\end{tabular}

Source:prepared by the researcher.

Notes: - ***, ** and * are significant at the $1 \%, 5 \%$ and $10 \%$ levels respectively.

The results of the previous table confirm what was concluded using the Baron and Kenny's Bars test, where the statistical results of the three tests were significant for the determinants of market acuity, fluid partnering, business continuity planning, and organizational learning. It was not significant for to change disposition and information technology.

Thus, these results confirm that strategic agility plays a role as a "holistic mediation" in the relationship of market acuity, fluid partnering to organizational performance, while playing a role as a "partial mediation" in the relationship of business continuity planning, and organizational learning to organizational performance. Strategic agility does not play a role as a mediator in the relationship of chage disposition, and information technology to organizational performance. 


\section{\& For structural model general statistics:}

Finally, by moving to the following table (5), it displays general statistics for the study model such as the determination factor Statistics (R2), the Wald Test Statistics, which assumes that all route parameters except the fixed part are zero for each equation in the model, and the model's stability test.

Table (5): Equation goodness of fit statistics (R-squared \& Wald test \& Stability test):

\begin{tabular}{|c|c|c|c|c|c|c|}
\hline \multirow[t]{2}{*}{ Depvars } & \multirow{2}{*}{$\begin{array}{c}R- \\
\text { squared }\end{array}$} & \multicolumn{3}{|c|}{ Wald tests for equations } & \multicolumn{2}{|c|}{$\begin{array}{c}\text { Eigenvalue stability } \\
\text { condition }\end{array}$} \\
\hline & & chi2 & $d f$ & Prob. & Eigenvalue & Modulus \\
\hline \multicolumn{7}{|l|}{ Observed: } \\
\hline Strategic Agility & $\% 86.3$ & 709.74 & 6 & $0.000 * * *$ & $\mathbf{0}$ & $\mathbf{0}$ \\
\hline $\begin{array}{l}\text { Organizational } \\
\text { Performance }\end{array}$ & $\% 96.3$ & 152.95 & 7 & $0.000 * * *$ & $\mathbf{0}$ & $\mathbf{0}$ \\
\hline Overall & $\% 92.7$ & & & & Stability I & Idex $=0$ \\
\hline
\end{tabular}

Source: prepared by the researcher.

Notes: - ***, ** and * are significant at the $1 \%, 5 \%$ and $10 \%$ levels respectively.

The previous table(5) shows that the six antecedents of strategic agility explain $86.3 \%$ of changes in the strategic agility of pharmaceutical companies. The rest of the ratio of 13.7 is due to random error, which may be due to many other administrative factors that are not controlled here in the structural model. Strategic agility and the antecedents explain 96. $3 \%$ of changes in the organizational performance of pharmaceutical companies. The rest of the ratio is due to random error, and based on the coefficient of the two equations, the coefficient of the whole structural model is equal to 92.7 , a very high rating indicating the accuracy of the study model's description, which also reflects an excellent fit level. 
The previous table also shows that a test value (CHII2) was statistically at $\% 1$ for each of the study model equations, indicating that the numeric hypothesis that route parameters other than the fixed part were zero, thereby accepting the alternative hypothesis that all model path parameters were zero. That is, the study model as a whole is statistically important at $\% 1$. Finally, the stability test in the table suggests that the model meets the stability requirement as a whole, with the stability indicator worth zero.

\section{Conclusion}

The research aimed at studying the impact of strategic Agility antecedents on Strategic Agility and Organizational Performance. The results showed that strategic Agility Antecedents has a positive impact on both Strategic Agility and Organizational performance, and Strategic Agility mediates the relationship between Strategic Agility antecedents and Organizational performance. The research presented a set of Recommendations, including :-

- The need to deepen the managerial thought related to Strategic management of the companies under study because of its contribution to enhance the ability of the company to achieve better performance to ensure its survival and growth.

- Expanding the relationship between the companies departments and university professors through organizing training courses, scientific seminars, practical conferences or workshops related to the area of strategic agility.

- Provide an effective incentive system for employees to gain their support during the planning and implementation processes. 


\section{Refrences}

- Abu -Radi, Samir,(2013), Strategic agility and its impact on the operations competitive capabilities in Jordanian private hospitals , (Master thesis), Middle East University.

- Adler,Nira,(2012),The Strategically Agile Organization : Development of a Measurement Instrument. (Doctoral dissertation), Alliant International University, ProQuest,UMI Dissertations Publishing.

- Carpenter,Mason A.\&Sanders,W.g.(2006)," Strategic Management A dynamic Perspective" , Prentice-Hall, New Jersey.

- Figge,F.(2011),"Development of a sustainability Balanced score card : translating Strategy Into value Based sustainability management" , Journal of the Asia Spesific Center for Environmental of The Accountability, Vol,8, No,1,P5.

- Hoek,RemkoI.Van , Harrison,A.\&Christopher,M.2001,"Measuring Agile Capabilities In The Supply chain ", International journal Of Management,21(1/2),126-147.

- Jones,R.A.,Jimmieson,N.L\&Griffith,A.(2005)"The Impact of Organizational Culture and Reshaping Capabilities Of Change ImplementationSuccess; The mediating Role Of Readiness for change " Journal of Management studies,42(2),361-386.

- Kagwa,J.,(2015),"Influence of Strategic Agility on Competitive Capability of Private Universities in Kenya ", Master Thesis ,School of Business , University of Nairobi.

- Kettunen.O.,2010"Agile Product Development and strategic Agility in Technology Firms", Master Degree ,Helsinki University of Technology ,Espoo,Finland.

- Kirca ,A.H.,Jayachandran,s.,\&Bearden.W.O.(2005),"Market Orientation : A Meta -Analytic Review and Assessment Of Its 
Antecedents and Impact On -Journal Of Marketing,69(April),2441.

- Meer, etal.,(2000):" Evaluation and Organizational Learning Of BELEIPSWETENCHAP,14(3),P.253

- Morganti,M.(2002),"A business Continuity Plan Keeps You in Business Professional Safety",47(1),19.

- Ojha,D.(2008),"Impact Of Strategic Agility On Competitive Capabilities and Financial Performance", (Doctoral Dissertation), The Graduate School Of Clemson University, South California.

- OgollaJudith,Thomas.,(2017),"Relationship between Strategic Agility and Organizational Performance ", International Journal of Management ,2(3),73-79.

- Ogunsiji,Akanbi,(2013)," The Role Of Perceived Environmental Uncetainty and Strategic Agility On The Performance Of Selected Banks In Oyo State Of Nigeria", Information Knowledge Management,vol(3).

- Tallon,P.Patrick,(2007),"Inside The Adaptive Enterprise : An Information Technology Capabilities Perspective On Business Process Agility"

- Vagnoni,E.,andKhoddami,S.,(2016)," DesignningCompetitivity Model Through The Strategic Agility Approach in A Turbulent Environment".,Foresight,18(6):625-648.

- Yeganegi,K.Azar(2012)," The effect of It on Organizational Agility Procedings"of the 2012 International Conference On Industrial Engineering and Operations,Management,Istanbul,Turkey. 
ملخص

هدفت الدراسة إلى قياس تأثير محددات الرشاقة الاستراتيجية على الأداء التظظيمي بتوسيط الرشاقة الاستراتيجية، وأيضا قياس تأثير الرشاقة الاستراتيجية على الأداء التنظيمي، و استخدمت الباحثة المنهج الوصفي التحليلي ، وتم تجميع البيانات من خلال قائمة استقصاء، تم توجيهها لمديري الإدارة العليا و الوسطى في الثركات محل الاراسة البالغ عددهم فى العينة (266) بمعدل استجابة (\%87,6) ، و تم تحليل البيانات من خلال برنامج (SPS 26 )، و برنامج ( STATA 16) ، باستخدام مجموعة من أساليب الإحصاء اللامعلمية. و توصلت الدراسة إلى وجود تأثير إيجابي لكافة محددات الرشاقة الاستراتيجية على كلا من الأداء التنظيمي و الرشاقة الاستراتيجية ، و بينت أيضا أن الرشاقة الاستراتيجية تلعب دورا وسيطا في علاقة محددات الرشاقة الاستراتيجية بالأداء التنظيمي . مصطلحات البحث: الرشاقة الإستراتيجية ، الأداء التظيمى ، محددات، شركات الأدوية. 